\title{
Evaluating the Sensitivity and Efficacy of Fungicides with Different Modes of Action Against Botryosphaeria dothidea
}

Yingying Song, Institute of Plant Protection, Shandong Academy of Agricultural Sciences, Jinan, P.R. China; and Department of Entomology, College of Plant Protection, Nanjing Agricultural University, Laboratory of Insect Information and Ecology, Nanjing 210095, P.R. China; Lili Li, Chao Li, Zengbin Lu, and Xingyuan Men, ${ }^{\dagger}$ Institute of Plant Protection, Shandong Academy of Agricultural Sciences; and Fajun Chen, Department of Entomology, College of Plant Protection, Nanjing Agricultural University, Laboratory of Insect Information and Ecology

\begin{abstract}
Botryosphaeria dothidea, the causal agent of apple ring rot, is an important fungal plant pathogen that can cause serious reductions in crop yield, and fungicides still play a crucial role in management. In the present study, the sensitivity of $B$. dothidea to fludioxonil, fluazinam, and pyrisoxazole was assessed in 162 isolates. Moreover, the protective and curative activity of the three fungicides on detached apple fruit as well as the control efficacy in the field were determined. The results showed that the mean $50 \%$ effective concentration $\left(\mathrm{EC}_{50}\right)$ values ( \pm standard deviation) were $0.01 \pm 0.008,0.04 \pm 0.03$, and $0.02 \pm 0.01 \mu \mathrm{g} \mathrm{ml}^{-1}$, with individual $\mathrm{EC}_{50}$ values of 0.002 to $0.05,0.003$ to 0.19 , and 0.005 to $0.26 \mu \mathrm{g} \mathrm{ml}^{-1}$ for fludioxonil, fluazinam, and pyrisoxazole, respectively. In addition, the

frequency distributions of $\mathrm{EC}_{50}$ values were both unimodal curves. However, significant correlations $(P<0.05)$ were found between fludioxonil and iprodione, between fluazinam and iprodione, as well as between pyrisoxazole and difenoconazole. In field trials conducted during 2016 and 2017, the control efficacy ranged from 75.91 to $87.41 \%$ when fludioxonil was applied at 100 to $150 \mathrm{mg}$ active ingredient (a.i.) $\mathrm{kg}^{-1}, 81.90$ to $85.13 \%$ when fluazinam was applied at $400 \mathrm{mg}$ a.i. $\mathrm{kg}^{-1}$, and 77.43 to $80.97 \%$ when pyrisoxazole was applied at $400 \mathrm{mg}$ a.i. $\mathrm{kg}^{-1}$. The control efficacy of the fungicides in storage was higher than $60 \%$, with the exception of fluazinam. These results demonstrated that fludioxonil, fluazinam, and pyrisoxazole have considerable potential to control apple ring rot.
\end{abstract}

Apple ring rot, which is caused by Botryosphaeria dothidea (Moug.) Ces. \& De Not (Tang et al. 2012), is a destructive disease that adversely affects yields in apple production areas all over the world (Brown and Britton 1986; Jurick et al. 2013; Marsberg et al. 2017; Vasić et al. 2013; Xu et al. 2015). The Fuji cultivar has good fruit quality and is widely planted in China; however, it is more sensitive to B. dothidea than other cultivars (Kang et al. 2009). Symptoms of the disease on fruit appear as slightly sunken lesions with alternating dark and light-brown circular rings, and the incidence of decayed fruit may reach 30 to $40 \%$ before harvest and more than $70 \%$ in storage (Xiang 1957; Zhang et al. 2012). In addition, the pathogen can also infect branches and trunks, leading to a high number of cankers and tree fatality in severe cases (Tang et al. 2012).

Although traditional cultivation practices such as apple bagging technology, pruning out affected branches, and girdling have been used to protect apple orchards from $B$. dothidea, these practices are labor intensive and successive years of girdling can lead to reduced tree health (Dai et al. 2017). Currently, preventive application of fungicides with multiple chemical groups is still an effective strategy for managing $B$. dothidea. A number of fungicides have been registered against apple ring rot, including benzimidazoles (carbendazim and thiophanate-methyl), sterol demethylation inhibitors (DMI; flusilazole and tebuconazole), and dithiocarbamate (mancozeb) (Brown-Rytlewski and McManus 2000; Fan et al. 2016; Liu et al. 2010). However, tebuconazole, carbendazim, and thiophanatemethyl resistance have emerged in populations of $B$. dothidea because of their extensive application (Wang et al. 2010; Yang and Liu 2002). Consequently, there is an urgent need to identify

${ }^{\dagger}$ Corresponding author: X. Men; E-mail: menxy2000@hotmail.com

Funding: This study was supported by the National Key R\&D Program of China (2017YFD0200400), Key R\&D Program of Shandong Province (2017CXGC0214), and Agricultural Science and Technology Innovation Project of Shandong Academy of Agricultural Sciences (CXGC2016A09).

Accepted for publication 27 March 2018.

(c) 2018 The American Phytopathological Society low-risk and more effective fungicides to retain sustainable management of $B$. dothidea.

Fludioxonil is an analog of antibiotic pyrrolnitrin, produced by various Pseudomonas spp. (Nishida et al. 1965). It has favorable efficacy against many fungal pathogens belonging to the classes Deuteromycetes, Basidiomycetes, and Ascomycetes (Gehmann et al. 1990; Keinath 2015; Yang and Jiao 2007). Although the mode of action of fludioxonil is unknown, it has been shown to activate Hog1type mitogen-activated protein kinase in plant-pathogenic fungi (Kojima et al. 2004; Yoshimi et al. 2005), indicating that it may disrupt the osmoregulation pathway (X. Li et al. 2014). Fluazinam, a preventative phenylpyridinamine fungicide, has been reported to control a wide range of diseases due to its high efficacy (Lehner et al. 2017; Shao et al. 2015; Smith et al. 2008). Its functional mechanism is to interrupt the synthesis of adenosine triphosphate, which is essential for fungal metabolism, by uncoupling mitochondrial oxidative phosphorylation (Vitoratos 2014). There is a low risk of resistance to fluazinam due to its multiple-site mode of action (Lehner et al. 2017). Indeed, there are few to no reports of fluazinam resistance in plant-pathogenic fungi. Pyrisoxazole, belonging to a subgroup of pyridines, was developed by Shenyang Research Institute of Chemical Industry, Shenyang, China. The target site is 14- $\alpha$ sterol demethylase in sterol biosynthesis (Han et al. 2006). Although it has broad-spectrum fungicide activity ( $\mathrm{Si}$ et al. 2004), pyrisoxazole was solely registered for controlling gray mold caused by Botrytis cinerea in China (China Pesticide Information Network, http://www.chinapesticide.org.cn/).

Because fludioxonil, fluazinam, and pyrisoxazole have not yet been registered for the control of apple ring rot, it is timely to evaluate the sensitivity of Botryosphaeria dothidea to the three fungicides prior to their legal use (Russell 2004). Therefore, the objectives of this study were to (i) establish the baseline sensitivity of $B$. dothidea to fludioxonil, fluazinam, and pyrisoxazole; (ii) assess the multiple resistance patterns between these fungicides and other widely used fungicides; (iii) determine the preventative and curative activity of the fungicides on apple fruit under controlled environmental conditions; and (iv) test the efficacy in the field.

\section{Materials and Methods}

Fungicides. Technical-grade fludioxonil (active ingredient [a.i.] 95\%), fluazinam (a.i. 98\%), difenoconazole (a.i. 95\%), tebuconazole (a.i. 97\%), thiophanate-methyl (a.i. 95\%), carbendazim (a.i. 98\%), 
mancozeb (a.i. 90\%), and iprodione (a.i. 96\%) were provided by Shandong Weifang Rainbow Chemical Co., Ltd. Pyrisoxazole (a.i. 90\%) was provided by Shenyang Kechuang Chemical Co., Ltd. These fungicides were used to establish baseline sensitivity and to determine $B$. dothidea resistance. To prepare stock solutions of $1 \times 10^{4}$ $\mu \mathrm{g} \mathrm{ml} l^{-1}$, fluazinam, pyrisoxazole, difenoconazole, thiophanatemethyl, mancozeb, and iprodione were dissolved in acetone; fludioxonil and tebuconazole were dissolved in methanol; and carbendazim was dissolved in hydrochloric acid $(\mathrm{HCl})$. Then, stock solutions were stored at $4{ }^{\circ} \mathrm{C}$ in the dark. For in vivo assessment, formulated fludioxonil (50\% WP; Syngenta Crop Protection [Suzhou] Co., Ltd.), fluazinam (50\% SC; Shenzhen Noposion Agrochemicals Co., Ltd.), pyrisoxazole (25\% EC; Shenyang Kechuang Chemicals Ltd.), mancozeb (80\% WP; Sinon Chemical Co., Ltd.), thiophanate-methyl (80\% WG; Shaanxi Thompson Biological Technology Co., Ltd.), carbendazim (80\% WG; Shandong Weifang Rainbow Chemical Co., Ltd.), and captan $(50 \%$ WP; Shandong Weifang Rainbow Chemical Co., Ltd.) were used.

Fungal isolates. In total, 162 single-conidium isolates of $B$. dothidea were collected from diseased apple trees in 17 cities of Shandong Province, China, during 2014 to 2015. The identity of all isolates in the study was confirmed by morphology, phylogenetic analysis, and pathogenicity testing. The sampled trees had not been previously exposed to any phenylpyrrole, phenylpyridinamine, or pyridine fungicides. All isolates were used to determine the baseline sensitivity to fludioxonil, fluazinam, and pyrisoxazole. Isolates (60 isolates/ fungicide) exhibiting different levels of sensitivity to difenoconazole, tebuconazole, thiophanate-methyl, carbendazim, mancozeb, and iprodione (data not shown) were used to determine multiple resistance patterns. For long-term storage, all isolates were maintained at $-80^{\circ} \mathrm{C}$ in $80 \%$ (vol/vol) glycerol.

Baseline sensitivity to fludioxonil, fluazinam, and pyrisoxazole. Measurements of baseline sensitivity to fludioxonil, fluazinam, and pyrisoxazole were performed on the 162 isolates of $B$. dothidea. Determination of the fungicide concentration resulting in a 50\% inhibition compared with the control $\left(\mathrm{EC}_{50}\right)$ was performed according to Myresiotis et al. (2007), with minor modifications. Briefly, the fungicides were respectively added to molten half-strength potato dextrose agar (PDA) after cooling to $55^{\circ} \mathrm{C}$ to obtain final concentrations of active ingredient at $0.001,0.005,0.01,0.05,0.1,0.5$, and $1 \mu \mathrm{g} \mathrm{ml}^{-1}$, and then dispensed into petri dishes ( 90 by $15 \mathrm{~mm}$ ). PDA supplemented with $0.2 \%$ methanol was used as a control for the fludioxonil test, while $0.2 \%$ acetone was added as a control for fluazinam and pyrisoxazole tests. Mycelial plugs ( 5 by $5 \mathrm{~mm}$ ) were cut from the periphery of 3-day-old colonies of each isolate and placed mycelial-side down in the center of fungicide-amended and control PDA plates. Each isolate was represented by three replicate plates, which were incubated at $23^{\circ} \mathrm{C}$ for 3 days in the dark. Then, colony diameter (minus the original diameter of the inoculation plug) was determined as the average of two perpendicular measurements. The experiment was performed twice.

Multiple resistance patterns. For the multiple resistance assays, 60 isolates of $B$. dothidea were used. The sensitivities of these strains were estimated by determining the $\mathrm{EC}_{50}$ for mycelial growth for difenoconazole, tebuconazole, thiophanate-methyl, mancozeb, and iprodione. Concentrations of each fungicide were amended into PDA (difenoconazole at 0.001, 0.005, 0.01, 0.05, 0.1, 0.5, 1, and $5 \mu \mathrm{g} \mathrm{ml}^{-1}$; tebuconazole at $0.001,0.005,0.01,0.05,0.1,0.5,1,5$, and $10 \mu \mathrm{g} \mathrm{ml}^{-1}$; thiophanate-methyl at $0.05,0.1,0.5,1,5,10,50,100$, and $500 \mu \mathrm{g} \mathrm{ml}^{-1}$; carbendazim at $1,5,10,50,100,500,1,000$, and $2,000 \mu \mathrm{g} \mathrm{ml}^{-1}$; mancozeb at $0.05,0.1,0.5,1,5,10,50,100$, and $500 \mu \mathrm{g} \mathrm{ml}^{-1}$; and iprodione at $0.005,0.01,0.05,0.1,0.5,1$, 5 , and $10 \mu \mathrm{g} \mathrm{ml}^{-1}$ ) and $\mathrm{EC}_{50}$ values were determined as described for baseline sensitivity assays. There were three replicate plates per fungicide, and the experiment was performed twice.

Preventative and curative activity of fludioxonil, fluazinam, and pyrisoxazole against $\boldsymbol{B}$. dothidea on apple. Fuji apple fruit were used to evaluate the preventative and curative activity of fludioxonil, fluazinam, and pyrisoxazole according to a previously described method (Fan et al. 2017), with minor modifications. Fruit were collected from a commercial market and selected on the basis of shape and size uniformity, similar physiological maturity, and no treatment with fungicide. The fruit were washed with $0.5 \%$ (vol/vol) sodium hypochlorite solution, then rinsed with sterile water and air dried.

Fruit were sprayed either with fludioxonil at dose concentrations of 100,150 , and $200 \mu \mathrm{g} \mathrm{ml}^{-1}$ or fluazinam and pyrisoxazole at dose concentrations of 100, 200, and $400 \mu \mathrm{g} \mathrm{ml}^{-1}$. Formulated mancozeb, thiophanate-methyl, and carbendazim at doses of $1,000 \mu \mathrm{g} \mathrm{ml}^{-1}$ were used as reference fungicides. For controls, fruit were sprayed with deionized water using a hand-held sprayer (Xinmeir Co. Ltd.). The treated fruit were air dried for $1 \mathrm{~h}$. Fungicides were applied to fruit $24 \mathrm{~h}$ after inoculation with $B$. dothidea (curative treatment) or prior to inoculation (protective treatment).

B. dothidea isolate QX-5 was sensitive to fludioxonil, fluazinam, pyrisoxazole, mancozeb, thiophanate-methyl, and carbendazim. Conidial suspensions of the isolate were prepared at a concentration of $1.0 \times 10^{5} \mathrm{ml}^{-1}$ according to Leng et al. (2009). Two wounds were inflicted at the equator of each fruit with a fine sterile needle and inoculated by pipetting $20 \mu \mathrm{l}$ of conidial suspension. Control fruit were treated with sterile water. After treatment application, all fruit were placed in plastic trays at $25^{\circ} \mathrm{C}$ for 12 days. To maintain high relative humidity, the insides of the trays were sprayed with sterile distilled water. Ten replicate fruit were used for each treatment and the experiment was performed three times. The mean diameters of rotting lesions were measured in two perpendicular directions around each wound. Then the protective and curative control efficacy was calculated using the following formula: Control efficacy $(\%)=[($ average lesion diameter of control fruit - average lesion diameter of treated fruit)/(average lesion diameter of control fruit)] $\times 100$.

Field trials. Field experiments were done on 25-year-old Fuji variety trees in Laiwu City in Shandong Province in 2016 and 2017. Plants were naturally infected with $B$. dothidea in the field. In all, 2 plants/plot and 11 plots were arranged in a randomized design with four replicates. The application began at the initiation of disease in early May using a Jacto Heavy-Duty HD 400 sprayer (Agrolex) and the spray volume was 4 liters/plant. The fungicide treatments were as follows: treatments 1 and 2: fludioxonil (WP 50\%) applications of 100 and $150 \mathrm{mg}$ a.i. $\mathrm{kg}^{-1}$, treatments 3 and 4: fluazinam (SC $50 \%$ ) applications of 200 and $400 \mathrm{mg}$ a.i. $\mathrm{kg}^{-1}$, treatments 5 and 6 : pyrisoxazole (EC 25\%) applications of 200 and $400 \mathrm{mg}$ a.i. $\mathrm{kg}^{-1}$, treatment 7: mancozeb (WP 80\%) applications of 1,000 mg a.i. $\mathrm{kg}^{-1}$, treatment 8: thiophanate-methyl (WG 80\%) applications of 1,000 $\mathrm{mg}$ a.i. $\mathrm{kg}^{-1}$, treatment 9: captan (WP 50\%) applications of 1,000 $\mathrm{mg}$ a.i. $\mathrm{kg}^{-1}$, treatment 10: carbendazim (WG 80\%) applications of 1,000 mg a.i. $\mathrm{kg}^{-1}$, and treatment 11: a water treatment control (CK). Fungicides were sprayed seven times at 14-day intervals.

The total numbers of fruit and diseased fruit on each tree were recorded 10 days after the last spraying. Then, 25 symptom-free fruit were harvested randomly from every tree in five different locations, with 50 fruit/plot. The harvested fruit were transported to the laboratory and kept at room temperature. Disease incidence was surveyed after 15 and 30 days of storage. The disease incidence and control efficacy of the fungicides were calculated according to Fan et al. (2016): Disease incidence $=($ the number of diseased fruit/total fruit $) \times$ $100 \%$ and Control efficacy $=[$ (disease incidence of CK - disease incidence of treated plot)/(disease incidence of CK) $] \times 100 \%$.

Data analyses. All data were processed using the SAS statistical software package (version 9.2; SAS Institute). The $\mathrm{EC}_{50}$ values of each isolate were calculated by plotting the relative inhibition against the $\log _{10}$ of the fungicide concentration used. Before multiple resistance analyses between pairs of fungicides, the $\mathrm{EC}_{50}$ values were transformed to $\log _{10}$ values and the correlation coefficients $(r)$ were calculated. To detect differences between treatments, the means of control efficacy were arcsine transformed, then compared with Fisher's least significant difference test $(P<0.05)$.

\section{Results}

Baseline sensitivity to fludioxonil, fluazinam, and pyrisoxazole. The $\mathrm{EC}_{50}$ values of the $162 \mathrm{~B}$. dothidea isolates were tested for sensitivity to fludioxonil, fluazinam, and pyrisoxazole on the basis of mycelial growth. The frequency distributions of the $\mathrm{EC}_{50}$ values both fit unimodal curves (fludioxonil: Kolmogorov-Smirnov, $P=0.98$; 
fluazinam: Kolmogorov-Smirnov, $P=0.79$; and pyrisoxazole: Kolmogorov-Smirnov, $P=0.55$ ). For fludioxonil, the individual $\mathrm{EC}_{50}$ values ranged from 0.002 to $0.05 \mu \mathrm{g} \mathrm{ml}^{-1}$, and the range-of-variation factor (VF; the highest $\mathrm{EC}_{50}$ value/the lowest $\mathrm{EC}_{50}$ value) was 25 , while the mean $\mathrm{EC}_{50}$ had a value ( \pm standard deviation) of $0.01 \pm 0.008 \mu \mathrm{g} \mathrm{ml}^{-1}$ (Fig. 1A). For fluazinam, the values ranged from 0.003 to $0.19 \mu \mathrm{g} \mathrm{ml}^{-1}$, with a mean value of $0.04 \pm 0.03 \mu \mathrm{g} \mathrm{ml}^{-1}$, and the VF value was 63 (Fig. 1B). For pyrisoxazole, the $\mathrm{EC}_{50}$ values varied from 0.005 to $0.26 \mu \mathrm{g} \mathrm{ml}^{-1}$, with an average of $0.02 \pm 0.01 \mu \mathrm{g} \mathrm{ml}^{-1}$ and VF value of 52 (Fig. 1C).

Correlation of fludioxonil, fluazinam, and pyrisoxazole sensitivity with sensitivity to other fungicides. The sensitivity to fludioxonil (or fluazinam or pyrisoxazole) was plotted against the sensitivity to difenoconazole, tebuconazole, thiophanate-methyl, carbendazim, mancozeb, and iprodione (Figs. 2, 3, and 4). We found significant correlations $(P<0.05)$ between fludioxonil and iprodione $\mathrm{EC}_{50}$ values ( $r=0.31$ and $P=0.02)$, fluazinam and iprodione $\mathrm{EC}_{50}$ values $(r=0.34$ and $P=0.01)$, and pyrisoxazole and difenoconazole $\mathrm{EC}_{50}$ values $(r=$ 0.37 and $P=0.04$ ). There were no clear correlations between the $\mathrm{EC}_{50}$ values for fludioxonil (or fluazinam or pyrisoxazole) and other common fungicides $(P>0.05)$.

Preventative and curative activity on apple. Experiments on detached apple fruit indicated that fludioxonil, fluazinam, and pyrisoxazole provided excellent preventative control efficacy against B. dothidea (Table 1). Applications of fludioxonil at 100, 150, and $200 \mu \mathrm{g} \mathrm{ml}^{-1}$ showed significantly higher efficacy, ranging from 82.41 to $93.89 \%$, than the three reference fungicides. At the highest concentration of fluazinam (i.e., $400 \mu \mathrm{g} \mathrm{ml}^{-1}$ ) and pyrisoxazole (i.e., $400 \mu \mathrm{g} \mathrm{ml}^{-1}$ ) tested, the efficacy reached 80.85 and $75.55 \%$, respectively, and there was no significant difference with the control efficacy of mancozeb, which was $78.51 \%$ at a concentration of $1,000 \mu \mathrm{g} \mathrm{ml}^{-1}$. For curative activity, fludioxonil, fluazinam, and pyrisoxazole were observed to be effective and the control efficacy was greater than $60 \%$, except in the case of pyrisoxazole at $100 \mu \mathrm{g} \mathrm{ml}^{-1}$, which exhibited statistically significantly lower fungicidal activity than mancozeb, thiophanate-methyl, and carbendazim.

Field trials. The results of field trials during 2016 and 2017 showed that the control efficacy of fludioxonil at a dosage of $150 \mathrm{mg}$ a.i. $\mathrm{kg}^{-1}$ and fluazinam at $400 \mathrm{mg}$ a.i. $\mathrm{kg}^{-1}$ ranged from 84.01 to 87.41 and 81.90 to $85.13 \%$, respectively, which was significantly higher $(P<0.05)$ than that of thiophanate-methyl, captan, and carbendazim at a dosage of 1,000 $\mathrm{mg}$ a.i. $\mathrm{kg}^{-1}$ (Table 2). The $100 \mathrm{mg}$ a.i. $\mathrm{kg}^{-1}$ fludioxonil rate and $400 \mathrm{mg}$ a.i. $\mathrm{kg}^{-1}$ pyrisoxazole rate were not significantly different $(P>0.05)$ from the efficacy of mancozeb at $1,000 \mathrm{mg}$ a.i. $\mathrm{kg}^{-1}$ and thiophanate-methyl at $1,000 \mathrm{mg}$ a.i. $\mathrm{kg}^{-1}$ over 2 years. This indicated that fludioxonil, fluazinam, and pyrisoxazole succeeded in controlling apple ring rot before harvest.

After 15 days postharvest, fludioxonil (i.e., 100 and $150 \mathrm{mg} \mathrm{a.i.} \mathrm{kg}^{-1}$ ) and pyrisoxazole (i.e., 200 and $400 \mathrm{mg}$ a.i. $\mathrm{kg}^{-1}$ ) achieved excellent inhibitory effect, ranging from 70.91 to $78.93 \%$ in 2016 and 65.88 to $74.54 \%$ in 2017 . In addition, fluazinam at $400 \mathrm{mg}$ a.i. $\mathrm{kg}^{-1}$ also showed satisfactory control efficacy and it was significantly different $(P<0.05)$ from the reference fungicides of thiophanate-methyl and carbendazim at $1,000 \mathrm{mg}$ a.i. $\mathrm{kg}^{-1}$.

When the storage period was extended, the severity of apple ring rot increased, especially with fluazinam at $200 \mathrm{mg}$ a.i. $\mathrm{kg}^{-1}$, even

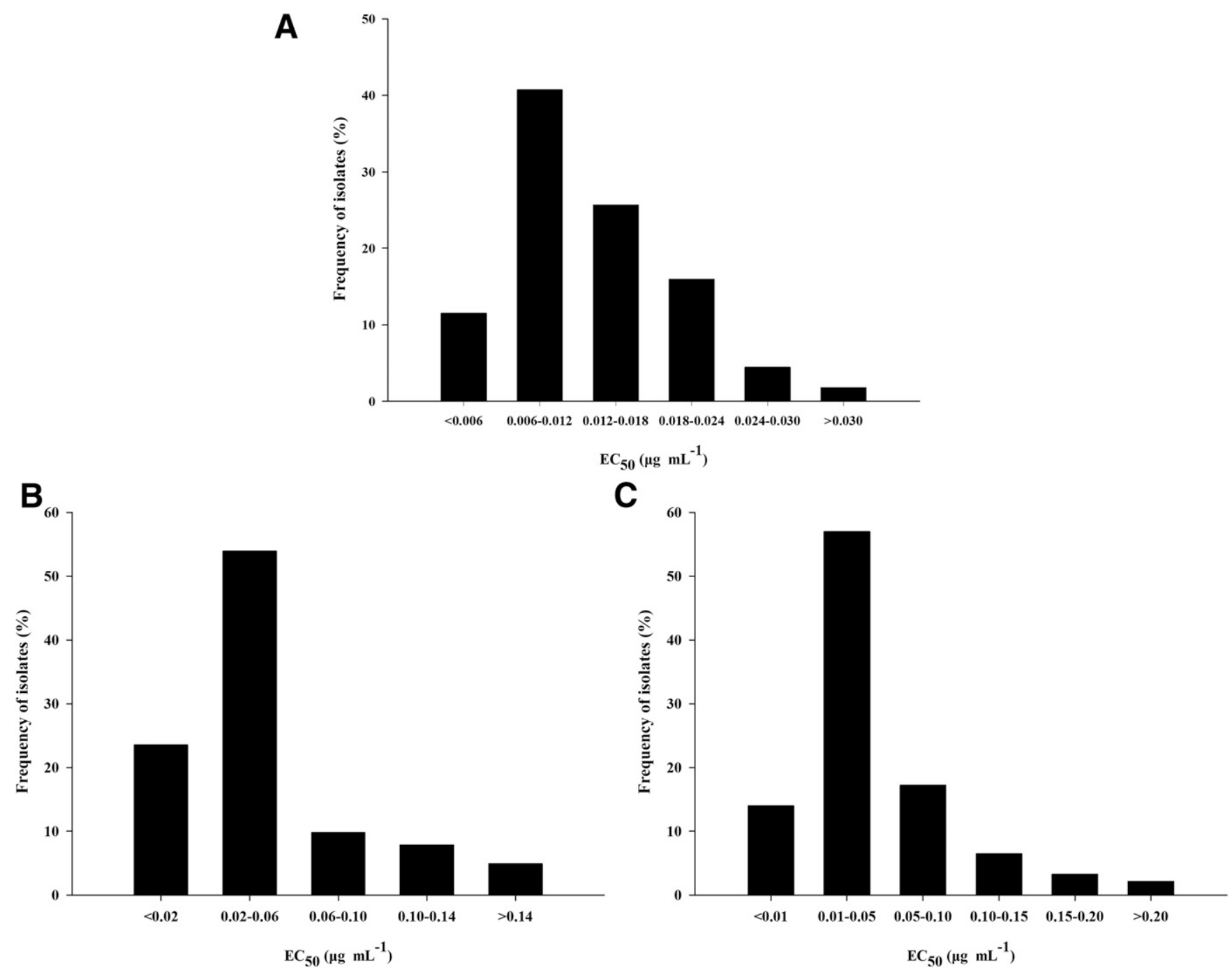

Fig. 1. Frequency distributions of $50 \%$ effective concentration $\left(E C_{50}\right)$ of 162 Botryosphaeria dothidea isolates treated with $\mathbf{A}$, fludioxonil; $\mathbf{B}$, fluazinam; and $\mathbf{C}$, pyrisoxazole based on mycelial growth. $\mathrm{EC}_{50}$ values were calculated by performing a regression of the percentage relative growth against the $\log _{10}$ fungicide concentration. 
though its control efficacy was similar to mancozeb, thiophanatemethyl, and captan after 30 days of storage. From 2016 to 2017, the highest dose of fludioxonil treatment still achieved the best efficacy (above 70\%).

\section{Discussion}

In China, fungicides are often extensively applied to control apple ring rot and reduce the risk of commercial loss. However, several studies have reported that some registered and commonly used fungicides such as tebuconazole, carbendazim, and thiophanate-methyl have reduced efficacy to control B. dothidea of apple (Fan et al. 2016; Yang and Liu 2002). Therefore, we evaluated the sensibility of nine fungicides, including fludioxonil, fluazinam, pyrisoxazole, pyraclostrobin, flusilazole, thifluzamide, myclobutanil, fluopyram, and boscalid, against $B$. dothidea in our laboratory (data not shown). Nevertheless, only fludioxonil, fluazinam, and pyrisoxazole were highly effective in

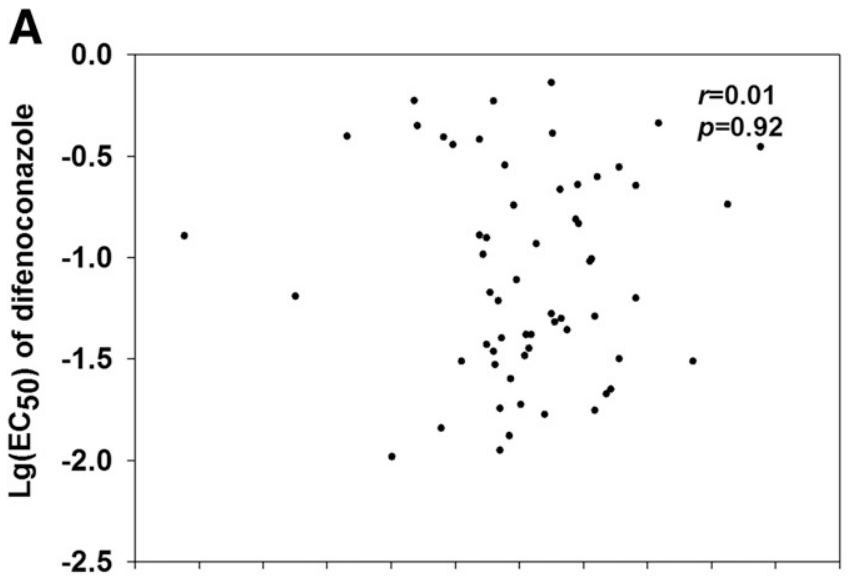

$-3.2-3.0-2.8-2.6-2.4-2.2-2.0-1.8-1.6-1.4-1.2-1.0$

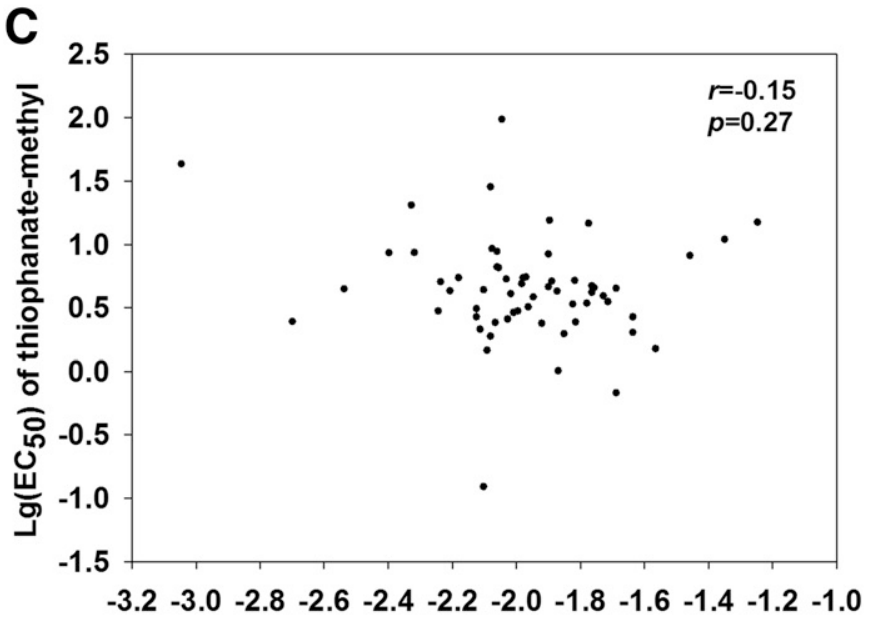

E

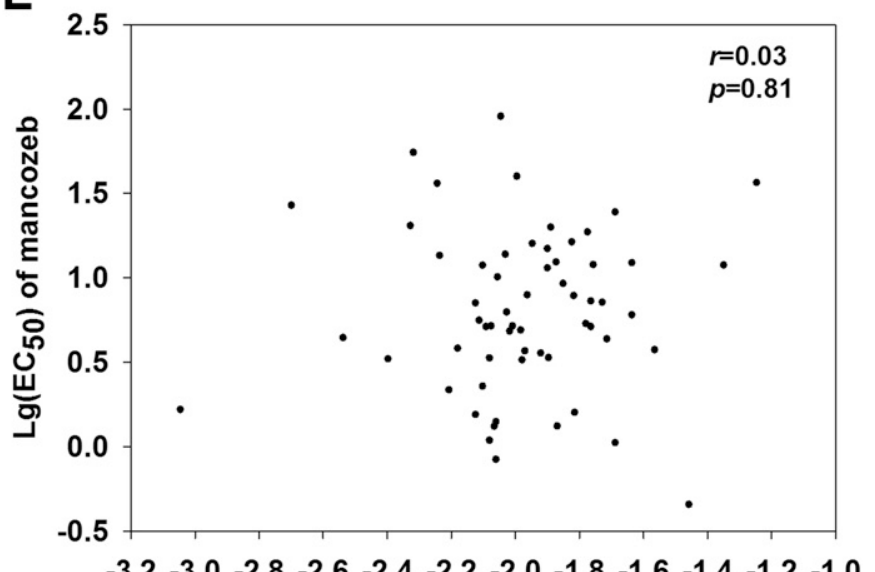

$-3.2-3.0-2.8-2.6-2.4-2.2-2.0-1.8-1.6-1.4-1.2-1.0$
B

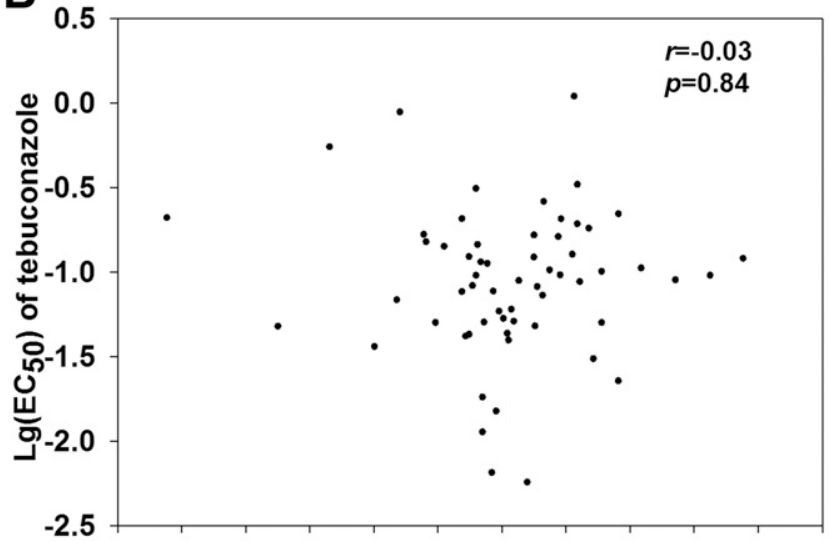

$-3.2-3.0-2.8-2.6-2.4-2.2-2.0-1.8-1.6-1.4-1.2-1.0$

D

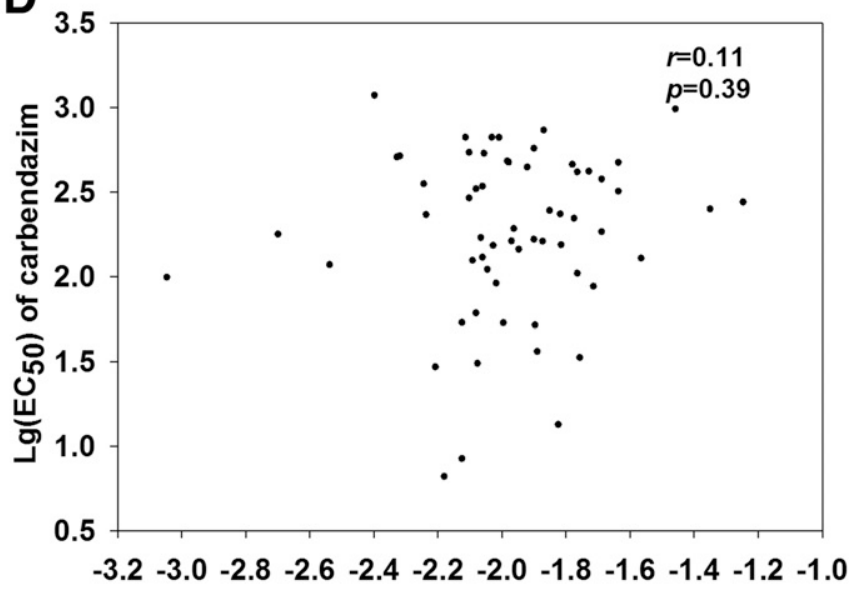

$\mathbf{F}$

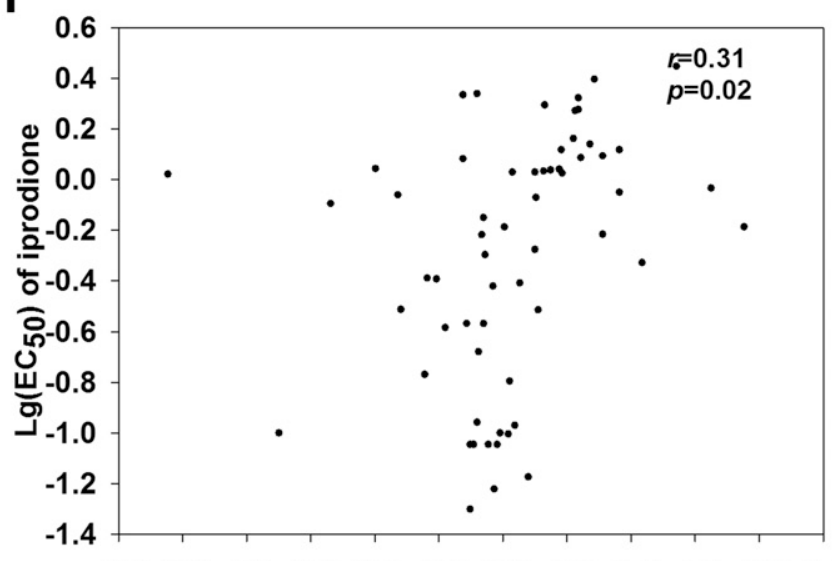

$-3.2-3.0-2.8-2.6-2.4-2.2-2.0-1.8-1.6-1.4-1.2-1.0$

\section{$\mathrm{Lg}\left(\mathrm{EC}_{50}\right)$ of fludioxonil}

Fig. 2. Pearson correlation coefficients of sensitivity of 60 Botryosphaeria dothidea isolates to fludioxonil and sensitivity to A, difenoconazole; B, tebuconazole; C, thiophanatemethyl; D, carbendazim; E, mancozeb; and F, iprodione. The sensitivity of 60 Botryosphaeria dothidea to each fungicide was tested based on mycelial growth on potato dextrose agar media and the $50 \%$ effective concentration $\left(\mathrm{EC}_{50}\right)$ values were transformed to $\log _{10}$ values. The sensitivity to fludioxonil was plotted against the sensitivity to six other fungicides. 
repressing mycelial growth. In order to prolong the use deadline for registered fungicides and improve their sustained efficacy against apple ring rot, we assessed the activity of fludioxonil, fluazinam, and pyrisoxazole under controlled-environment and field conditions.

Baseline sensitivity data are valuable for fungicide resistance management, because they can provide evidence of shifts in pathogen sensitivity and help to monitor the development of resistance in the future. In the present study, the baseline sensitivity distributions were both unimodal among the 162 isolates of $B$. dothidea, which suggested that no resistant subpopulations had developed ( $\mathrm{S}$. Li et al. 2014). Therefore, the sensitivity range can be used as respective baseline sensitivities of $B$. dothidea to fludioxonil, fluazinam, and pyrisoxazole. For fludioxonil, the VF was 25 , and the narrow sensitivity range
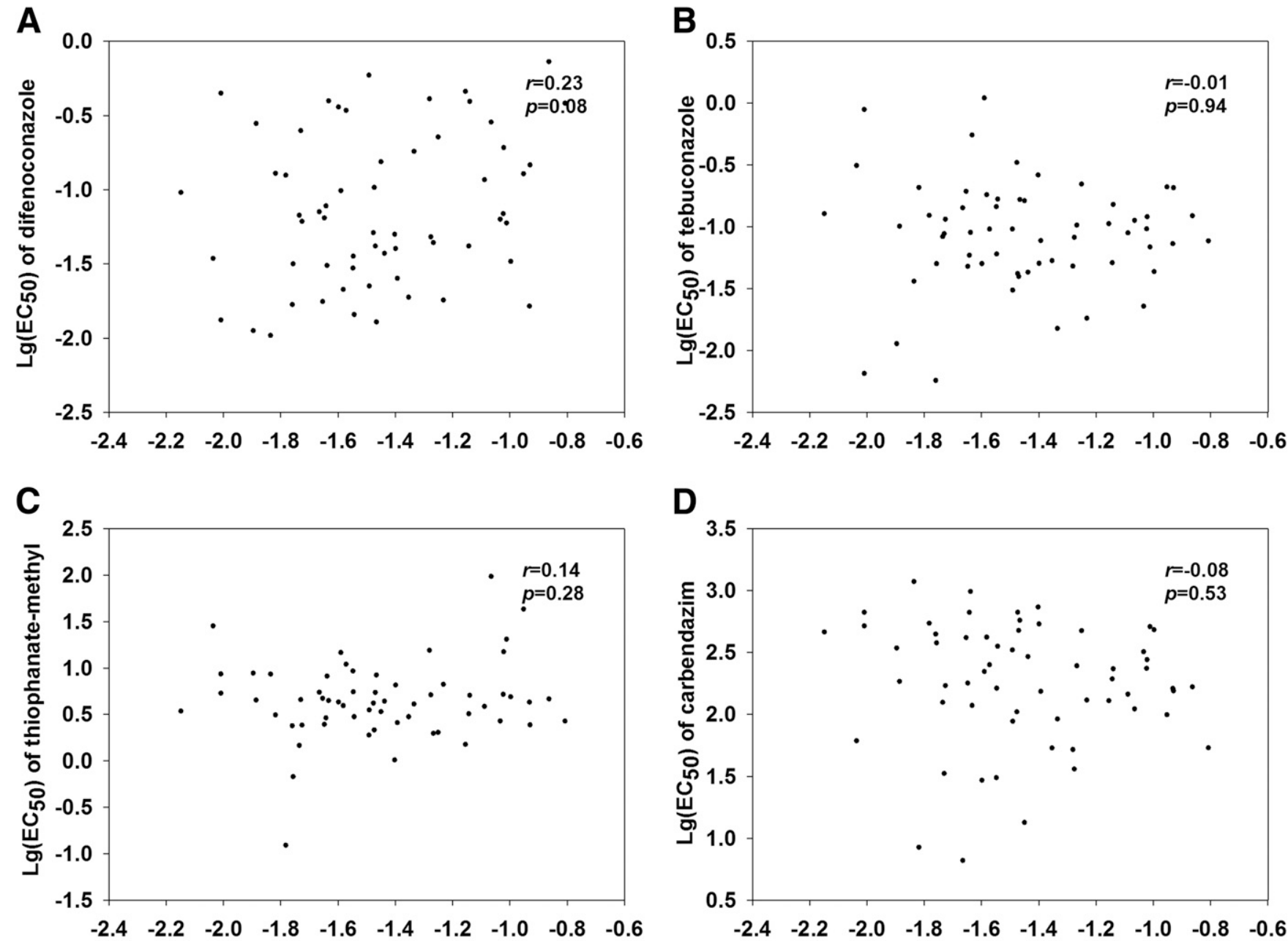

D

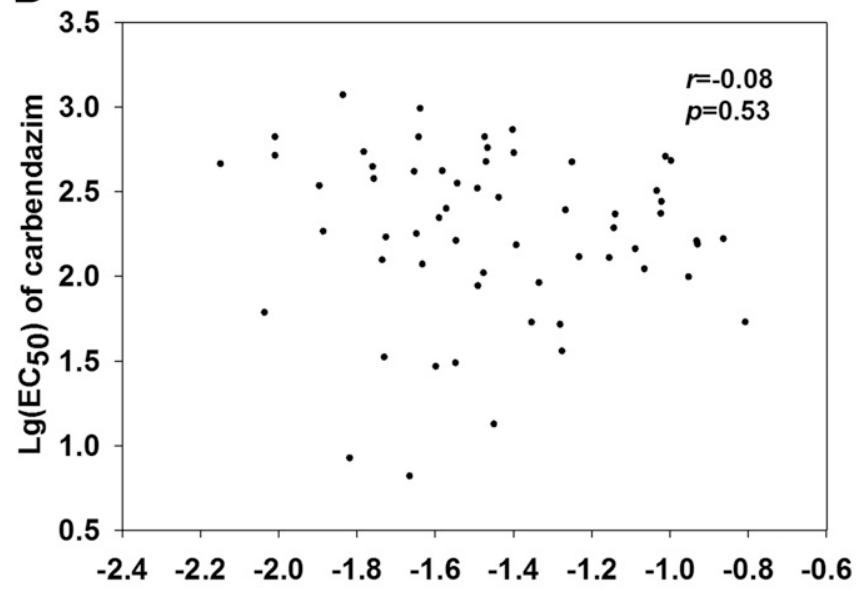

E

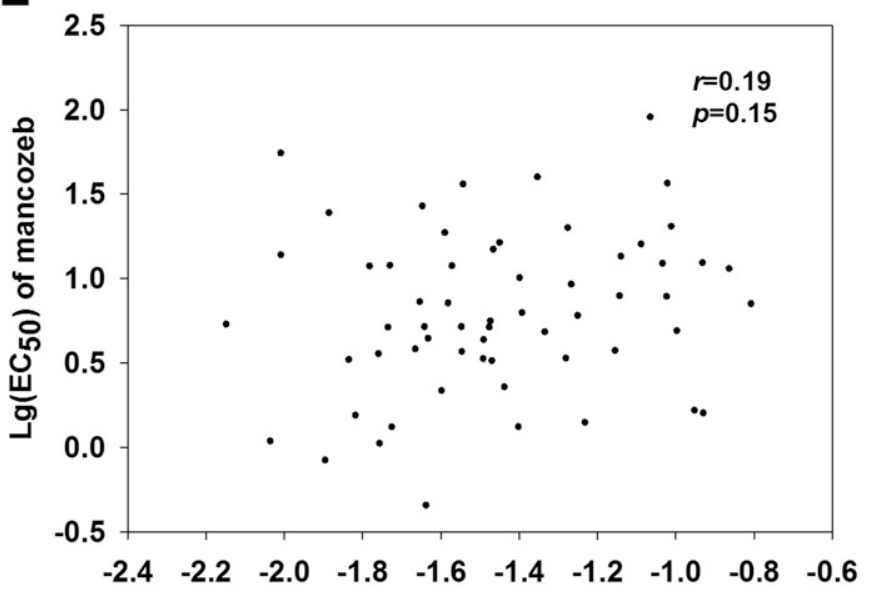

$\mathbf{F}$

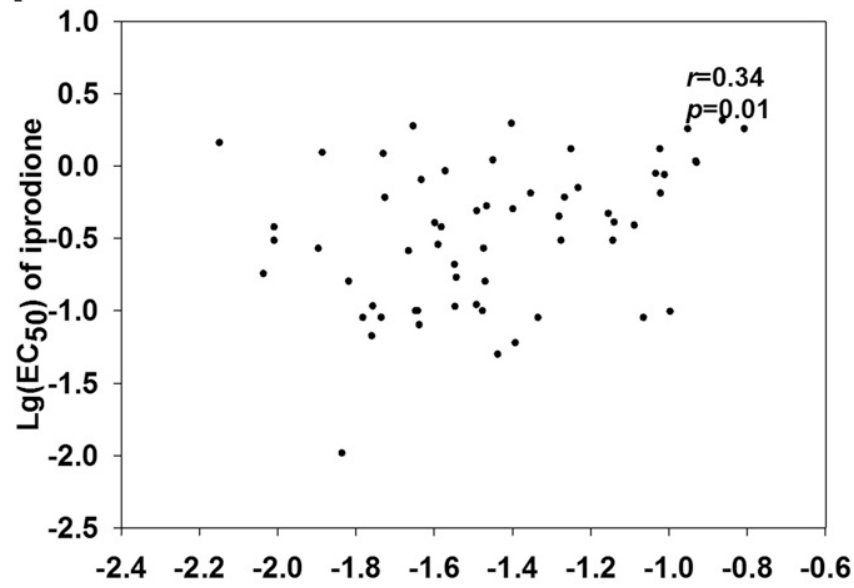

\section{$\operatorname{Lg}\left(E_{50}\right)$ of fluazinam}

Fig. 3. Pearson correlation coefficients of sensitivity of 60 Botryosphaeria dothidea isolates to fluazinam and sensitivity to A, difenoconazole; B, tebuconazole; C, thiophanatemethyl; D, carbendazim; E, mancozeb; and F, iprodione. The sensitivity of 60 Botryosphaeria dothidea to each fungicide was tested based on mycelial growth on potato dextrose agar media and the $50 \%$ effective concentration $\left(\mathrm{EC}_{50}\right)$ values were transformed to $\log _{10}$ values. The sensitivity to fluazinam was plotted against the sensitivity to six other fungicides. 
was similar to that of several other pathogens such as Penicillium expansum (Karaoglanidis et al. 2011), Botrytis cinerea (Liu et al. 2016), and P. digitatum (Fu et al. 2015). However, the VF values of fluazinam and pyrisoxazole were both $>50$, which were in contrast with previous studies (Chen et al. 2012; Lehner et al. 2017; Zhu et al. 2016). These differences may suggest that Botryosphaeria dothidea will be more likely to develop resistance to fluazinam and pyrisoxazole than other pathogen populations after continuous contact with these two fungicides in the field.

The effectiveness of fludioxonil, fluazinam, and pyrisoxazole was tested on detached apple fruit and in field conditions. Although effective curative activity was observed, the three fungicides may be best applied preventively or at the early stage of infection, because eradication becomes more challenging once $B$. dothidea has penetrated
A

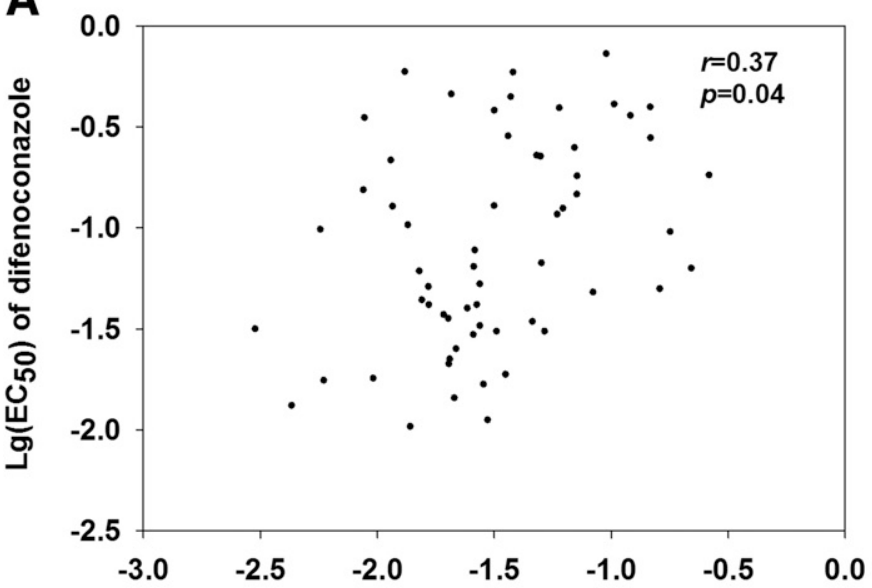

C

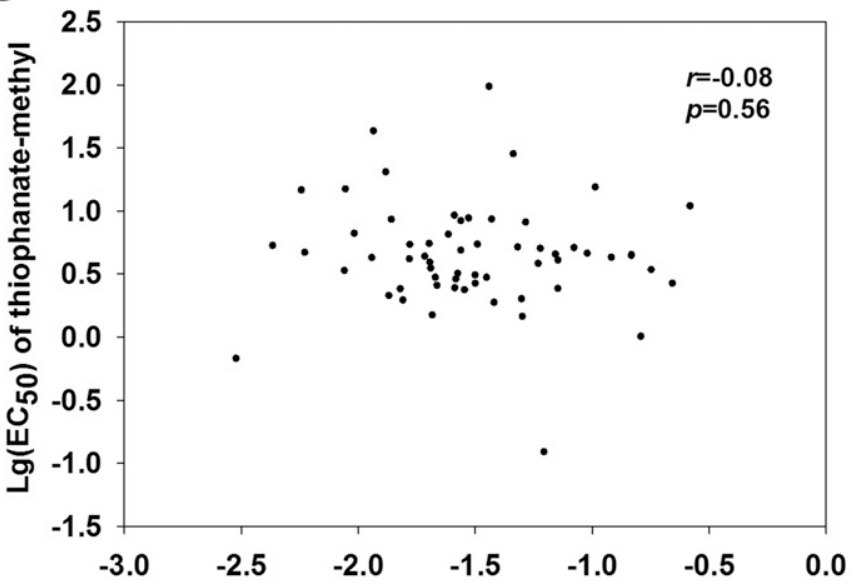

E

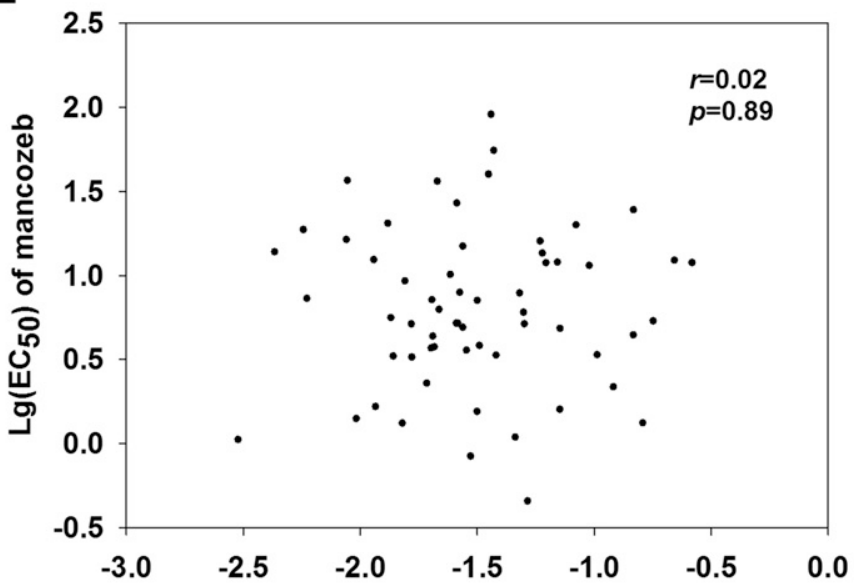

B

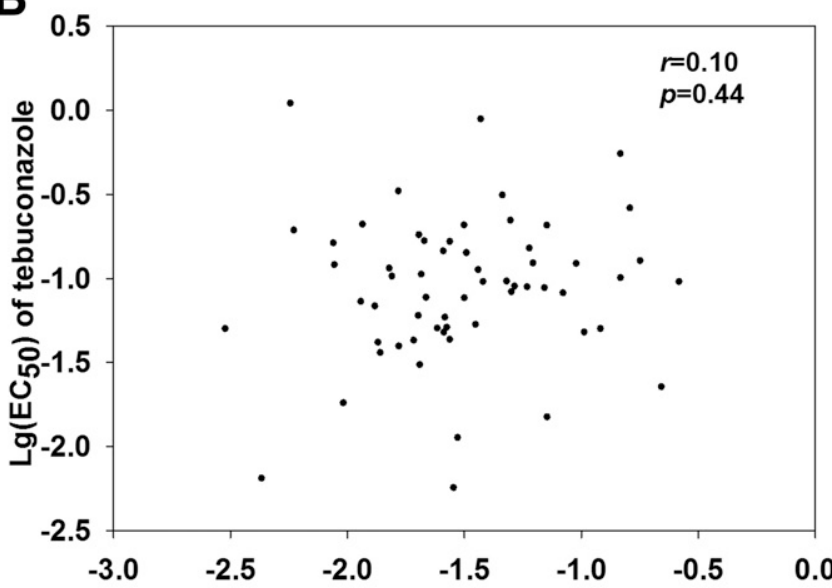

D

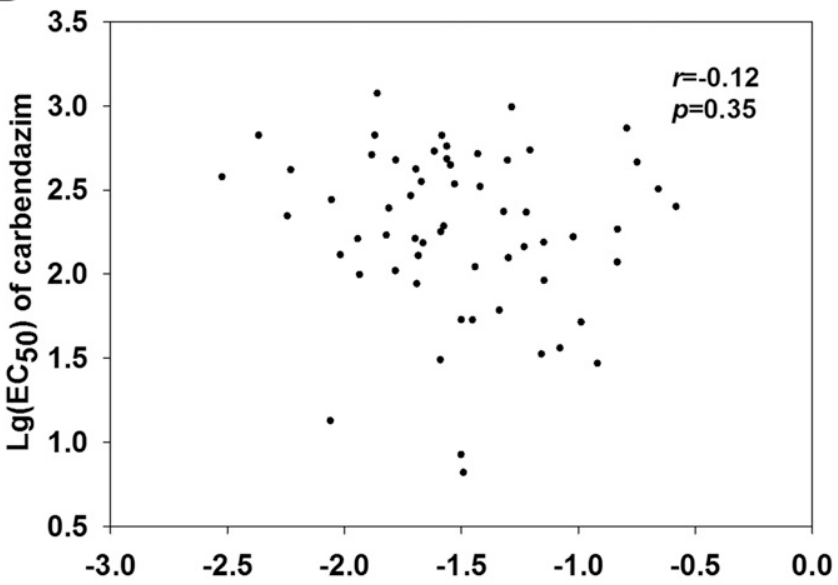

$\mathbf{F}$

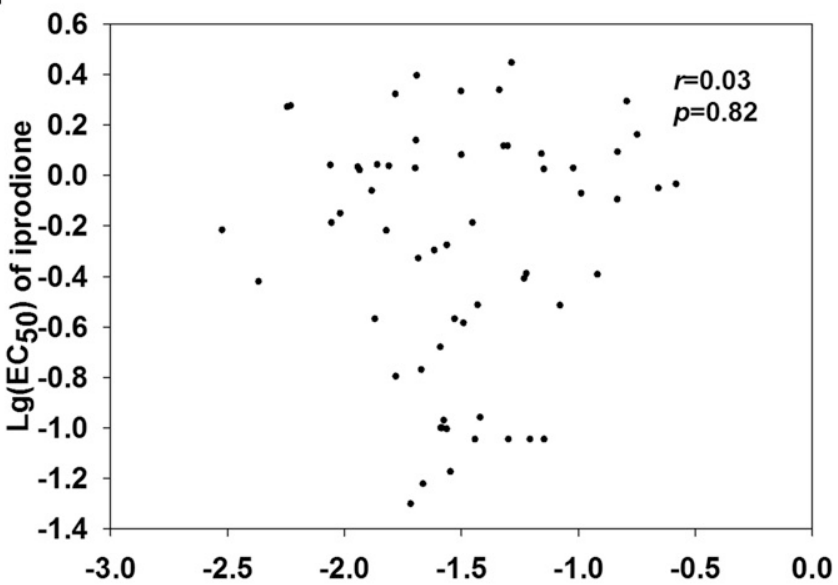

$\operatorname{Lg}\left(\mathrm{EC}_{50}\right)$ of pyrisoxazole

Fig. 4. Pearson correlation coefficients of sensitivity of 60 Botryosphaeria dothidea isolates to pyrisoxazole and sensitivity to A, difenoconazole; $\mathbf{B}$, tebuconazole; $\mathbf{C}$, thiophanatemethyl; D, carbendazim; E, mancozeb; and F, iprodione. The sensitivity of 60 Botryosphaeria dothidea to each fungicide was tested based on mycelial growth on potato dextrose agar media and the $50 \%$ effective concentration $\left(E_{50}\right)$ values were transformed to $\log _{10}$ values. The sensitivity to pyrisoxazole was plotted against the sensitivity to six other fungicides. 
healthy plant tissues (Brown-Rytlewski and McManus 2000). The low efficacy of carbendazim observed in the present study may be related to high-level resistance, which has been frequently detected in our laboratory (data not shown). In the storage experiment, mancozeb was observed to be effective, and it has been registered for the control of apple ring rot in China (China Pesticide Information Network); however, Belpoggi et al. (2002) found that it was carcinogenic in rats. Therefore, mancozeb should be banned for harvest and postharvest application. Fludioxonil showed satisfactory control efficacy in the storage period. Also, it has been successfully used to prevent various rots of stone fruit, pome fruit, and sweet potato and gummy stem blight of watermelon and muskmelon during harvest because of the short preharvest interval (Keinath 2015; X. Li et al. 2014). It is presumed that fludioxonil may be an excellent alternative fungicide against $B$. dothidea during storage. With the extension of storage, fluazinam and pyrisoxazole also exhibited satisfactory control efficacies that were not significantly lower than those of reference fungicides. In addition, the preharvest interval of fluazinam was 7 days (Dong et al. 2008) and pyrisoxazole was safer to users (Si et al. 2004). This suggested that fluazinam and pyrisoxazole should be used to control apple ring rot before harvest. Fludioxonil, fluazinam, and pyrisoxazole not only showed high efficacy but also greatly reduced the dosage of fungicide required, which is of benefit to the environment compared with mancozeb, thiophanate-methyl, captan,

Table 1. Protective and curative activity of fludioxonil, fluazinam, and pyrisoxazole against Botryosphaeria dothidea on detached apple fruit ${ }^{\mathrm{x}}$

\begin{tabular}{|c|c|c|c|c|c|}
\hline \multirow[b]{2}{*}{ Treatmenty } & \multirow[b]{2}{*}{ Dose $\left(\mu \mathrm{g} \mathrm{ml}^{-1}\right)^{\mathrm{z}}$} & \multicolumn{2}{|c|}{ Protective activity } & \multicolumn{2}{|c|}{$\begin{array}{c}\text { Curative activity } \\
\end{array}$} \\
\hline & & Lesion $(\mathrm{cm})$ & Control (\%) & Lesion $(\mathrm{cm})$ & Control (\%) \\
\hline \multirow{3}{*}{ Fludioxonil } & 100 & 0.58 & $82.41 \mathrm{c}$ & 0.70 & $79.57 \mathrm{c}$ \\
\hline & 150 & 0.38 & $88.62 \mathrm{~b}$ & 0.50 & $85.14 \mathrm{~b}$ \\
\hline & 200 & 0.20 & $93.89 \mathrm{a}$ & 0.35 & $89.66 \mathrm{a}$ \\
\hline \multirow[t]{3}{*}{ Fluazinam } & 100 & 1.13 & $65.60 \mathrm{gh}$ & 1.30 & $61.69 \mathrm{~h}$ \\
\hline & 200 & 0.98 & $70.20 \mathrm{f}$ & 1.18 & $65.70 \mathrm{fg}$ \\
\hline & 400 & 0.63 & $80.85 \mathrm{~cd}$ & 0.78 & $77.37 \mathrm{~cd}$ \\
\hline \multirow[t]{3}{*}{ Pyrisoxazole } & 100 & 1.23 & $62.56 \mathrm{~h}$ & 1.50 & $56.07 \mathrm{i}$ \\
\hline & 200 & 0.95 & $71.06 \mathrm{f}$ & 1.08 & $68.60 \mathrm{f}$ \\
\hline & 400 & 0.80 & $75.55 \mathrm{e}$ & 0.88 & $74.69 \mathrm{de}$ \\
\hline Mancozeb & 1,000 & 0.70 & $78.51 \mathrm{de}$ & 0.90 & $73.66 \mathrm{e}$ \\
\hline Thiophanate-methyl & 1,000 & 0.98 & $70.24 \mathrm{f}$ & 1.23 & $64.24 \mathrm{gh}$ \\
\hline Carbendazim & 1,000 & 1.03 & $68.57 \mathrm{fg}$ & 1.28 & $62.73 \mathrm{gh}$ \\
\hline Control & $\ldots$ & 3.28 & $\ldots$ & 3.55 & $\ldots$ \\
\hline
\end{tabular}

${ }^{\mathrm{x}}$ Experiments were performed in the laboratory in 2016. Lesion $=$ lesion diameter and Control = control efficacy. Mean values followed by the same letter in the columns were not significantly different according to Fisher's least significant difference test at $P=0.05$.

y Each treatment was sprayed until runoff with a hand-held sprayer and air dried for $1 \mathrm{~h}$.

${ }^{\mathrm{z}}$ Dose $=$ effective concentration.

Table 2. Field control efficacy of fludioxonil, fluazinam, and pyrisoxazole on apple ring rot in 2016 and $2017^{y}$

\begin{tabular}{|c|c|c|c|c|c|c|c|c|c|c|c|c|}
\hline \multirow[b]{3}{*}{$\begin{array}{l}\text { Fungicides, dose } \\
\left(\mathrm{mg} \mathrm{a.i.}^{-1}\right)^{\mathbf{z}}\end{array}$} & \multicolumn{6}{|c|}{2016} & \multicolumn{6}{|c|}{2017} \\
\hline & \multicolumn{2}{|c|}{ In field } & \multicolumn{2}{|c|}{15 days postharvest } & \multicolumn{2}{|c|}{30 days postharvest } & \multicolumn{2}{|c|}{ In field } & \multicolumn{2}{|c|}{15 days postharvest } & \multicolumn{2}{|c|}{30 days postharvest } \\
\hline & $\begin{array}{l}\text { Disease } \\
\text { rate }\end{array}$ & $\begin{array}{c}\text { Control } \\
\text { efficacy } \\
(\%)\end{array}$ & $\begin{array}{l}\text { Disease } \\
\text { rate }\end{array}$ & $\begin{array}{c}\text { Control } \\
\text { efficacy } \\
(\%)\end{array}$ & $\begin{array}{l}\text { Disease } \\
\text { rate }\end{array}$ & $\begin{array}{c}\text { Control } \\
\text { efficacy } \\
(\%)\end{array}$ & $\begin{array}{l}\text { Disease } \\
\text { rate }\end{array}$ & $\begin{array}{c}\text { Control } \\
\text { efficacy } \\
(\%)\end{array}$ & $\begin{array}{l}\text { Disease } \\
\text { rate }\end{array}$ & $\begin{array}{c}\text { Control } \\
\text { efficacy } \\
(\%)\end{array}$ & $\begin{array}{l}\text { Disease } \\
\text { rate }\end{array}$ & $\begin{array}{c}\text { Control } \\
\text { efficacy } \\
(\%)\end{array}$ \\
\hline \multicolumn{13}{|l|}{$\begin{array}{l}\text { Fludioxonil } \\
\text { (WP) } 50 \%\end{array}$} \\
\hline 100 & 5.50 & 79.14 cde & 9.50 & $75.38 \mathrm{ab}$ & 17.00 & $68.69 \mathrm{ab}$ & 7.75 & $75.91 \mathrm{~cd}$ & 14.00 & $69.91 \mathrm{ab}$ & 21.00 & $66.41 \mathrm{ab}$ \\
\hline 150 & 3.25 & $87.41 \mathrm{a}$ & 8.00 & $78.93 \mathrm{a}$ & 14.50 & $73.45 \mathrm{a}$ & 5.13 & $84.01 \mathrm{a}$ & 12.00 & $74.54 \mathrm{a}$ & 18.50 & $70.35 \mathrm{a}$ \\
\hline \multicolumn{13}{|l|}{$\begin{array}{l}\text { Fluazinam } \\
\text { (SC) } 50 \%\end{array}$} \\
\hline 200 & 6.13 & $76.66 \mathrm{cdef}$ & 15.00 & $61.15 \mathrm{def}$ & 24.00 & $55.94 \mathrm{def}$ & 8.50 & $73.63 \mathrm{def}$ & 19.50 & 58.49 efg & 30.00 & $52.07 \mathrm{efg}$ \\
\hline 400 & 3.88 & $85.13 \mathrm{ab}$ & 12.50 & $67.05 \mathrm{~cd}$ & 21.50 & $60.50 \mathrm{~cd}$ & 5.88 & $81.90 \mathrm{ab}$ & 17.00 & $63.84 \mathrm{cde}$ & 25.00 & $59.93 \mathrm{~cd}$ \\
\hline \multicolumn{13}{|l|}{$\begin{array}{l}\text { Pyrisoxazole } \\
\text { (EC) } 25 \%\end{array}$} \\
\hline 200 & 6.88 & 73.88 efg & 11.00 & $70.91 \mathrm{bc}$ & 19.50 & $64.36 \mathrm{bc}$ & 9.50 & 70.76 efg & 16.00 & $65.88 \mathrm{bcd}$ & 23.50 & $62.38 \mathrm{bc}$ \\
\hline 400 & 4.88 & $80.97 \mathrm{bcd}$ & 10.00 & $74.24 \mathrm{ab}$ & 17.50 & $67.95 \mathrm{~b}$ & 7.25 & $77.43 \mathrm{bcd}$ & 15.00 & $68.01 \mathrm{bc}$ & 22.50 & $64.02 \mathrm{bc}$ \\
\hline \multicolumn{13}{|l|}{$\begin{array}{l}\text { Mancozeb } \\
\text { (WP) } 80 \%\end{array}$} \\
\hline 1,000 & 4.63 & $82.38 a b c$ & 13.50 & $65.08 \mathrm{cde}$ & 22.50 & $58.48 \mathrm{de}$ & 6.50 & $79.75 \mathrm{abc}$ & 18.00 & $61.62 \mathrm{def}$ & 27.50 & $56.03 \mathrm{de}$ \\
\hline \multicolumn{13}{|l|}{$\begin{array}{l}\text { Thiophanate- } \\
\text { methyl } \\
\text { (WG) } 80 \%\end{array}$} \\
\hline 1,000 & 6.38 & $75.89 \mathrm{def}$ & 15.50 & 59.28 ef & 27.00 & $50.26 \mathrm{fg}$ & 9.13 & $71.74 \mathrm{def}$ & 20.50 & $56.22 \mathrm{fg}$ & 31.50 & $49.54 \mathrm{fg}$ \\
\hline \multicolumn{13}{|l|}{$\begin{array}{c}\text { Captan (WP) } \\
50 \%\end{array}$} \\
\hline 1,000 & 7.38 & $71.55 \mathrm{fg}$ & 14.50 & $62.03 \mathrm{def}$ & 25.50 & 53.19 efg & 9.88 & $69.30 \mathrm{fg}$ & 18.50 & $60.62 \mathrm{def}$ & 28.50 & $54.39 \mathrm{def}$ \\
\hline \multicolumn{13}{|l|}{$\begin{array}{l}\text { Carbendazim } \\
\text { (WG) } 80 \%\end{array}$} \\
\hline 1,000 & 8.13 & $68.98 \mathrm{~g}$ & 16.50 & $56.92 \mathrm{f}$ & 28.00 & $48.56 \mathrm{~g}$ & 11.25 & $65.17 \mathrm{~g}$ & 22.00 & $53.09 \mathrm{~g}$ & 33.50 & $46.34 \mathrm{~g}$ \\
\hline Water control & 26.25 & $\ldots$ & 38.50 & $\ldots$ & 54.50 & $\ldots$ & 32.38 & $\ldots$ & 47.00 & $\ldots$ & 62.50 & $\ldots$ \\
\hline
\end{tabular}

${ }^{\mathrm{y}}$ Mean values followed by the same letter in the columns were not significantly different according to Fisher's least significant difference test at $P=0.05$.

${ }^{\mathrm{z}}$ Dose $=$ effective concentration. 
and carbendazim. Thus, fludioxonil, fluazinam, and pyrisoxazole have the potential to be excellent alternative fungicides for the control of apple ring rot and should be considered for registration in China.

Regarding cross-sensitivity, significant but slight correlations $(P<$ 0.05 ) between $\mathrm{EC}_{50}$ values of fludioxonil (or fluazinam) and iprodione as well as pyrisoxazole and difenoconazole were indicative of some level of multiple fungicide resistance. Hence, further research is necessary to understand the extent and nature of multiple resistance. Genetic analysis of fludioxonil-resistant isolates showed that a mutation in bos 1 that codes for group III histidine-kinases is associated with resistance to fludioxonil in filamentous fungi (Ochiai et al. 2002; Ren et al. 2016). Interestingly, the osmoregulation pathway of iprodione-resistant isolates was also disturbed and the mechanism of iprodione resistance was similar to that of fludioxonil (Fillinger et al. 2012; Grabke et al. 2014; Ochiai et al. 2002), which may result in the multiple resistance between fludioxonil and iprodione. Although fluazinam is listed as a low-risk fungicide, multipleresistance has also been observed between fluazinam and iprodione in Sclerotinia sclerotiorum (Liang et al. 2015) and Botrytis cinerea (Korolev et al. 2009). Shao et al. (2015) also reported that the fluazinam-resistant strain was also resistant to dicarboximide and highly sensitive to osmotic stress. Surprisingly, these changes were hardly relevant to fluazinam's mode of action in uncoupling oxidative phosphorylation. Pyrisoxazole and difenoconazole are DMI fungicides, and plant pathogen resistance to DMI is most commonly associated with (i) overexpression of the CYP51 gene, (ii) mutations in the CYP51 gene, and (iii) increased expression of energy-dependent drug efflux pumps (Délye et al. 1997; Nakaune et al. 1998; Schnabel and Jones 2001). Chen et al. (2012) believe that the first two mechanisms may play an important role in their economic importance. To date, not enough is known about the pathogen sensitivity correlation between pyrisoxazole and difenoconazole; therefore, an in-depth study is still required in order to well understand the resistance mechanisms involved.

To our knowledge, our research is the first to evaluate the baseline sensitivities and efficacies of fludioxonil, fluazinam, and pyrisoxazole against Botryosphaeria dothidea. In summary, these fungicides will be essential for apple ring rot management in the near future. However, to reduce the risk of fungicide resistance to $B$. dothidea, the implementation of fungicide rotation and selection of the most effective fungicide mixtures are necessary for users.

\section{Literature Cited}

Belpoggi, F., Soffritti, M., Guarino, M., Lambertini, L., Cevolani, D., and Maltoni, C. 2002. Results of long-term experimental studies on the carcinogenicity of ethylene-bis-dithiocarbamate (mancozeb) in rats. Ann. N. Y. Acad. Sci. 982: 123-136.

Brown, E. A. I., and Britton, K. O. 1986. Botryosphaeria diseases of apple and peach in the southeastern United States. Plant Dis. 70:480-484.

Brown-Rytlewski, D. E., and McManus, P. S. 2000. Virulence of Botryosphaeria dothidea and Botryosphaeria obtusa on apple and management of stem cankers with fungicides. Plant Dis. 84:1031-1037.

Chen, F. P., Fan, J. R., Zhou, T., Liu, X. L., Liu, J. L., and Schnabel, G. 2012. Baseline sensitivity of Monilinia fructicola from China to the DMI fungicide SYP-Z048 and analysis of DMI-resistant mutants. Plant Dis. 96:416-422.

Dai, D. J., Wang, H. D., Wang, Y. P., and Zhang, C. Q. 2017. Management of Chinese hickory (Carya cathayensis) trunk canker through effective fungicide application programs and baseline sensitivity of Botryosphaeria dothidea to trifloxystrobin. Australas. Plant Pathol. 46:75-82.

Délye, C., Laigre, F., and Coriocostet, M. F. 1997. A mutation in the 14 alphademethylase gene of Uncinula necator that correlates with resistance to a sterol biosynthesis inhibitor. Appl. Environ. Microbiol. 63:2966-2970.

Dong, F., Yang, S., and Liu, X. 2008. Determination of fluazinam in peppers and soils dynamic residues by gas chromatography with electron capture detector. Sci. Agric. Sin. 41:1684-1690.

Fan, H., Ru, J., Zhang, Y., Wang, Q., and Li, Y. 2017. Fengycin produced by Bacillus subtilis 9407 plays a major role in the biocontrol of apple ring rot disease. Microbiol. Res. 199:89-97.

Fan, K., Wang, J., Fu, L., Li, X., Zhang, Y., Zhang, X., Zhai, H., and Qu, J. 2016. Sensitivity of Botryosphaeria dothidea, from apple to tebuconazole in China. Crop Prot. 87:1-5.

Fillinger, S., Ajouz, S., Nicot, P. C., Leroux, P., and Bardin, M. 2012. Functional and structural comparison of pyrrolnitrin- and iprodione-induced modifications in the class III histidine-kinase Bos1 of Botrytis cinerea. PLoS One 7:e42520.
Fu, Y. S., Wang, M. S., Ruan, R. X., Zhu, C. Y., Sun, X. P., and Li, H. Y. 2015. Baseline sensitivity to fludioxonil of Penicillium digitatum population from citrus in China. Acta Agric. Zhejiangensis 27:68-74.

Gehmann, K., Nyfeler, R., Leadbeater, A. J., Nevill, D. J., and Sozzi, D. 1990 CGA 173506: A new phenylpyrrole fungicide for broad-spectrum disease control. Pages 369-376 in: Brighton Crop Prot. Conf. Pests Dis. 2.

Grabke, A., Fernándezortuño, D., Amiri, A., Li, X., Peres, N. A., and Smith, P. 2014. Characterization of iprodione resistance in Botrytis cinerea from strawberry and blackberry. Phytopathology 104:396-402.

Han, P., Liu, X., Liu, P., and Si, N. 2006. Effect of novel fungicide 5-(4-chloro phenyl)-2,3-dimethyl-3-(pyridine-3)-oxazoline on ergosterol biosynthesis in Botrytis cinerea by high performance liquid chromatography. Chin. J. Anal Chem. 34:1467-1470.

Jurick, W. M., II, Vico, I., Gaskins, V. L., Janisiewicz, W. J., and Peter, K. A. 2013. First report of Botryosphaeria dothidea causing white rot on apple fruit in Maryland. Plant Dis. 97:999.

Kang, L., Hao, H., Yang, Z., Li, X., and Kang, G. 2009. The advances in the research of apple ring rot. Chin. Agric. Sci. Bull. 25:188-191.

Karaoglanidis, G. S., Markoglou, A. N., Bardas, G. A., Doukas, E. G., Konstantinou, S., and Kalampokis, J. F. 2011. Sensitivity of Penicillium expansum, field isolates to tebuconazole, iprodione, fludioxonil and cyprodini and characterization of fitness parameters and patulin production. Int. J. Food Microbiol. 145:195-204.

Keinath, A. P. 2015. Baseline sensitivity of Didymella bryoniae to cyprodinil and fludioxonil and field efficacy of these fungicides against isolates resistant to pyraclostrobin and boscalid. Plant Dis. 99:815-822.

Kojima, K., Takano, Y., Yoshimi, A., Tanaka, C., Kikuchi, T., and Okuno, T 2004. Fungicide activity through activation of a fungal signalling pathway. Mol. Microbiol. 53:1785-1796.

Korolev, N., Mamiev, M., Zahavi, T., and Elad, Y. 2009. Resistance to fungicides among Botrytis cinerea isolates from tomato and other hosts in Israel. Acta Hortic. 808:367-376.

Lehner, M. S., Ponte, E. M. D., Gugino, B., Kikkert, J. R., and Pethybridge, S. J 2017. Sensitivity and efficacy of boscalid, fluazinam and thiophanate-methyl for white mold control in snap bean in New York. Plant Dis. 101:1253-1258.

Leng, W. F., Li, B. H., Guo, L. G., Dong, J. H., and Wang, C. X. 2009. Method to promote sporulation of Botryosphaeria berengeriana $\mathrm{f} \mathrm{sp}$. piricola. Acta Phytopathol. Sin. 39:88-91.

Li, S., Hou, Y., Peng, D., Meng, L., Wang, J., Zhou, M., and Chen, C. 2014 Baseline sensitivity and control efficacy of flutolanil in Rhizoctonia solani. Australas. Plant Pathol. 43:313-320.

Li, X., Fernándezortuño, D., Grabke, A., and Schnabel, G. 2014. Resistance to fludioxonil in Botrytis cinerea isolates from blackberry and strawberry. Phytopathology 104:724-732.

Liang, H. J., Di, Y. L., Li, J. L., and Zhu, F. X. 2015. Baseline sensitivity and control efficacy of fluazinam against Sclerotinia sclerotiorum. Eur. J. Plant Pathol. 142:691-699.

Liu, B., Wang, Y., Zhang, W., Luan, B., and Gai, Z. 2010. Research on the sensitivity of Botryosphaeria dothidea from apple to mancozeb. J. Anhui Agric. Sci. 38:9597-9598.

Liu, S., Hai, F., and Jiang, J. 2016. Sensitivity to fludioxonil of Botrytis cinerea isolates from tomato in Henan province of China and characterizations of fludioxonil-resistant mutants. J. Phytopathol. 165:98-104.

Marsberg, A., Kemler, M., Jami, F., Nagel, J. H., Postma-Smidt, A., Naidoo, S. Wingfield, M. J., Crous, P. W., Spatafora, J. W., Hesse, C. N., Robbertse, B., and Slippers, B. 2017. Botryosphaeria dothidea: A latent pathogen of global importance to woody plant health. Mol. Plant Pathol. 18:477-488.

Myresiotis, C. K., Karaoglanidis, G. S., and Tzavella-Klonari, K. 2007. Resistance of Botrytis cinerea isolates from vegetable crops to annilinopyrimidine, phenylpyrrole, hydroxyanilide, benzimidazole, and dicarboximide fungicides. Plant Dis. 91:407-413.

Nakaune, R., Adachi, K., Nawata, O., Tomiyama, M., Akutsu, K., and Hibi, T. 1998. A novel ATP-binding cassette transporter involved in multidrug resistance in the phytopathogenic fungus Penicillium digitatum. Appl. Environ. Microbiol. 64:3983-3988.

Nishida, M., Matsubara, T., and Watanabe, N. 1965. Pyrrolnitrin, a new antifunga antibiotic. Microbiological and toxicological observations. J. Antibiot. [B] 18: 211-219.

Ochiai, N., Fujimura, M., Oshima, M., Motoyama, T., Ichiishi, A., and YamadaOkabe, H. 2002. Effects of iprodione and fludioxonil on glycerol synthesis and hyphal development in Candida albicans. Biosci. Biotechnol. Biochem. 66:2209-2215.

Ren, W., Shao, W., Han, X., and Chen, C. 2016. Molecular and biochemical characterization of laboratory and field mutants of Botrytis cinerea resistant to fludioxonil in China. Plant Dis. 100:1414-1423.

Russell, P. E. 2004. Sensitivity Baselines in Fungicide Resistance Research and Management. FRAC Monograph 3. Crop Life International, Brussels.

Schnabel, G., and Jones, A. L. 2001. The 14a-Demethylase (CYP51A1) gene is overexpressed in Venturia inaequalis strains resistant to myclobutanil. Phytopathology 91:102-110.

Shao, W., Ren, W., Zhang, Y., Hou, Y., Duan, Y., and Wang, J. 2015. Baseline sensitivity of natural populations and characterization of resistant strains of Botrytis cinerea, to fluazinam. Australas. Plant Pathol. 44:375-383. 
Si, N. G., Zhang, Z. J., Liu, J. L., Li, Z. N., Zhan, D. M., Chen, L., and Wang, L. Z. 2004. Biological activity and application of a novel fungicide: SYP-Z048 (I). Chin. J. Pestic. 43:16-18.

Smith, D. L., Garrison, M. C., Hollowell, J. E., Isleib, T. G., and Shewa, B. B. 2008. Evaluation of application timing and efficacy of the fungicides fluazinam and boscalid for control of Sclerotinia blight of peanut. Crop Prot. 27:823-833.

Tang, W., Ding, Z., Zhou, Z. Q., Wang, Y. Z., and Guo, L. Y. 2012. Phylogenetic and pathogenic analyses show that the causal agent of apple ring rot in China is Botryosphaeria dothidea. Plant Dis. 96:486-496.

Vasić, M., Duduk, N., Vico, I., and Ivanović, M. S. 2013. First report of Botryosphaeria dothidea causing white rot of apple fruit in Serbia. Plant Dis. 97:1659.

Vitoratos, A. G. 2014. Mode of action and genetic analysis of resistance to fluazinam in Ustilago maydis. J. Phytopathol. 162:737-746.

Wang, Y. Z., Zhang, W., Liu, B. Y., Luan, B. H., and Wang, P. S. 2010. Research on resistance and geographical distribution of Botryosphaeria dothidea from apple to tebuconazole in Shandong province. J. Fruit Sci. 27:961-964.
Xiang, W. N. 1957. Reference of Mycology and Plant Pathology in China. Science Press, Beijing.

Xu, C., Wang, C., Ju, L., Zhang, R., Biggs, A. R., and Tanaka, E. 2015. Multiple locus genealogies and phenotypic characters reappraise the causal agents of apple ring rot in China. Fungal Divers. 71:215-231.

Yang, W. H., and Liu, K. Q. 2002. Resistance detection of Botryosphaeria berengeriana f. sp. piricola to carbendazim and thiophanate-methyl. Acta Phytophylac. Sin. 29:191-192.

Yang, Y., and Jiao, B. 2007. Advances in the research of a new fungicide fludioxonil. Mod. Agrochem. (Nanjing, China) 6:35-39.

Yoshimi, A., Kojima, K., Takano, Y., and Tanaka, C. 2005. Group III histidine kinase is a positive regulator of Hog1-type mitogen-activated protein kinase in filamentous fungi. Eukaryot. Cell 4:1820-1828.

Zhang, C., Zhang, T., Lu, X., Liu, Z., Zhang, Y., and Ma, S. 2012. Toxicity test of ten fungicides to Macrophoma kawatsukai and Colletotrichum gloeosporioides in laboratory. Chin. Agric. Sci. Bull. 28:236-240.

Zhu, H., Huang, C. T., and Ji, M. S. 2016. Baseline sensitivity and control efficacy of pyrisoxazole against Botrytis cinerea. Eur. J. Plant Pathol. 146:315-323. 